\title{
Administrasi Husemas
}

\author{
Asmaul husnah \\ Universitas Negeri Padang \\ Indonesia \\ E-mail : asmaulhusnah072837@gmail.com
}

\begin{abstract}
Abstrak- Husemas Administrator is the process of communication between schools and communities to further improve the school either in terms of facilities or others. Schools and communities both have one purpose where they expect children to have a good education and can become useful people for the future of Nusa and the nation.
\end{abstract}

\section{Keywords-(Husemas Administrator, schools)}

\section{PENDAHULUAN}

Sekolah merupakan tempat melaksanakan pendidikan. Disana siswa diajarkan tentang ilmu pengetahuan, nantinya akan diterapkan oleh siswa pada kehidupan sehari-hari ilmu yang telah di pelajarinya. Sekolah juga mengajarkan norma dan masih banyak lagi ilmu yang siswa terima disekolah.

Sekolah merupakan kunci untuk untuk masyarakat maju, dan masyarakat itu adalah kunci agar pendidikan dapat lebih maju. Dengan bantuan masyarakat terutama seperti masalah pembangunan dan juga masalah mengawasi siswa baik diluar lingkungan sekolah itu akan sangat membantu. Masyarakat adalah salah satu penunjang agar pendidikan dapat terlaksana dengan baik sebagaimana mestinya. Sekolah terletak ditengahtengah masyarakat. Dimana partisipasi masyarakat benarbenar dibutuhkan. pendidikan menjadi tanggung jawab bersama baik orang tua, guru serta masyarakat sekitar. Tingkat partisipasi masyarakat memiliki pengaruh yang besar terhadap kemajuan sekolah.

Bahkan Masyarakat dapat mempengaruhi prestasi hasil belajar siswa, dimana masyarakat biasanya bersama sekolah bekerjasama untuk membangun sesuatu yang dibutuhkan oleh siswa, atau juga membeli peralatan yang dibutuhkan siswa, untuk menunjang materi pelajaran, karena sesunguhnya pendididkan bukan hanya tanggung jawab guru saja melainkan juga tanggung jawab masyarakat sekitar seperti yang sudah dibahas di atas tadi. Jika masyarakat acuh atau tidak peduli sama sekolah maka pendidikan disana tidak akan mengalami kemajuan karena sekolah dan masyarakat harus memiliki hubungan yang baik, karena mereka adalah penunjang pendidikan maju.

Hubungan sekolah dengan masyarakat merupakan bentuk komunikasi ekstern yang dilakukan oleh lembaga sekolah atas dasar kesamaan tanggung jawab dan tujuan terhadap perkembangan pendidikan di sekolah, (Mulyasa, 2009:247148),

\section{Metode PENELITIAN}

Pada artikel Administrasi Husemas ini peneliti menggunakan metode studi literatur dimana Studi literatur adalah penelitian yang dilakukan menggunakan cara mengumpulkan materi dan membaca berbagai bacaan, baik majalah, buku-buku, artikel, jurnal yang sesuai dengan masalah atau materi yang akan peneliti bahas di penelitian. Sehingga dapat membantu dalam pembuatan penelitian dan dapat menyelesaikan masalah yang sedang di teliti, tentunya agar artikel juga dapat di pertanggung jawabkan nantinya. Menggunakan metode ini karena banyakya ilmu yang dapat peneliti petik dari berbagai sumber materi dan peneliti bisa lebih focus pada pembuatan artikel ini, karena tidak harus meneliti langsung, dikarenakan bahannya sudah ada di berbagai sumber materi terutama dari jurnal, karena banyak yang terbaru.

\section{KAJIAN TEORI DAN PEMBAHASAN}

\section{A. Pengertian Administrasi Pendidikan Husemas}

Hubungan antara sekolah dan masyarakat pada hakekatnya adalah suatu sarana yang cukup mempunyai peranan yang menentukan dalam rangka usaha mengadakan pembinaan pertumbuhan dan pengembangan murid-murid di sekolah. Secara umum orang dapat mengatakan apabila terjadi kontak, pertemuan dan lain-lain antara sekolah dengan orang di luar sekolah, adalah kegiatan hubungan sekolah dengan masyarakat. Arthur B. Mochlan menyatakan school public relation adalah kegiatan yang dilakukan sekolah atau sekolah untuk memenuhi kebutuhan masyarakat.

Ada suatu kebutuhan yang sama antara keduanya, baik dilihat dari segi edukatif, maupun dilihat dari segi psikologi. Hubungan antar sekolah dan masyarakat lebih dibutuhkan dan lebih terasa fungsinya, karena adanya kecenderungan perubahan dalam pendidikan yang menekankan perkembangan pribadi dan sosial anak melalui pengalaman-pengalaman anak dibawah bimbingan guru, baik diluar maupun di dalam sekolah.

Jadi Administasi Husemas adalah proses komunikasi antara sekolah dengan masyarakat untuk lebih meningkatkan sekolah baik dari segi fasilitas atau yang lainnya. Sekolah dan masyarakat sama-sama memiliki satu tujuan dimana mereka mengharapkan agar anak- anak memiliki pendidikan yang baik dan dapat menjadi orang yang berguna bagi nusa dan bangsa di masa depan nantinya.

\section{B. Prinsip-Prinsip dan Teknik- Teknik Administrasi Husemas}

\section{1) Prinsip-prinsip Administrasi Husemas}

a) Integrity 
Prinsip ini mengandung makna bahwa semua kegiatan hubungan sekolah dan masyarakat harus terpadu. Artinya informasi yang disampaikan antar keduanya harus informasi yang terpadu baik mengenai masalah akademik maupun non akademik. Hal ini sangat penting untuk meningkatkan penilaian dan kepercayan antar keduanya

\section{b) Continuity}

Prinsip ini menjelaskan bahwa hubungan ini harus dilakukan secara terus menerus, hal ini dilakukan agar masyarakat mengetahui perkembangan sekolah.

\section{c) Simplicity}

Prinsip menghendaki agar dalam proses hubungan sekolah dan masayarakat ini dapat menyederhanakan berbagai informasi yang disajikan kepada masyarakat sesuai dengan kondisi dan karakteristik masyarakat.

\section{d) Coverage}

Kegiatan pemberian informasi secara menyeluruh dan mencakup semua asfek, faktor atau subtansi yang perlu disampaikan dan perlu diketahui masyarakat.

\section{e) Constructiveness}

Program hubungan sekolah dengan masyarakat hendaknya konstruktif dalam arti sekolah memberikan informasi yang membangun pemahaman/pengetahuan masyarakat terhadap program pengembangan sekolah.

\section{f) Adaptability}

Program hubungan sekolah dengan masyarakat hendaknya disesuaikan dengan keadaan di dalam lingkungan masyarakat setempat.(Sagala, S. 2008)

\section{2) Teknik- teknik Administrasi Husemas}

\section{a) Teknik Tertulis}

Ada beberapa cara menggunakan teknik tertulis pertama Buku kecil pada permulaan tahun ajaran; Buku kecil pada permulaan tahun ajaran baru ini isinya dijelaskan tentang tata tertib, syarat-syarat masuk, hari-hari libur, hari-hari efektif. Kemudian buku kecil ini dibagikan kepada orang tua murid, hal ini biasanya dilaksanakan di taman kanak-kanak (TK). Kedua Pamflet; Pamflet merupakan selebaran yang biasanya berisi tentang sejarah lembaga pendidikan tersebut, staf pengajar, fasilitas yang tersedia, dan kegiatan belajar. Pamflet ini selain di bagikan ke wali murid juga bias di sebarkan ke masyarakat umum, selain untuk menumbuhkan pengertian masyarakat juga sekaligus untuk promosi lembaga. Ketiga Berita kegiatan murid; Berita ini dapat dibuat sederhana mungkin pada selebaran kertas yang berisi informasi singkat tentang kegiatan-kegiatan yang dilakukan di sekolah atu pesantren. Dengan membacanya orang tua murid mengetahui apa yang terjadi di lembaga pendidikan tersebut, khususnya kegiatan yang dilakukan murid. Keempat Catatan berita gembira; Teknik ini sebenarnya mirip dengan berita kegiatan murid, keduanya sama-sama ditulis dan disebarkan ke orang tua. Hanya saja catatan berita gembira ini berisi tentang keberhasilan seorang murid. Berita tersebut ditulis di selebaran kertas dan disampaikan kepada wali murid atau bahkan disebarkan ke masyarakat. Kelima Buku kecil tentang cara membimbing anak; Dalam rangka menciptakan hubungan yang harmonis dengan orang tua, kepala sekolah atau guru dapat membuat sebuah buku kecil yang sederhana yang berisi tentang cara membimbing anak yang efektif, kemudian buku tersebut diberikan kepada orang tua murid.

\section{b) Teknik Lisan}

Hubungan sekolah dengan masyarakat dapat juga lisan, yaitu: yang pertama Kunjungan rumah; Dalam rangka mengadakan hubungan dengan masyarakat, pihak sekolah dapat mengadakan kunjungan ke rumah wali murid, warga atupun tokoh masyarakat. Melalui kunjungan rumah ini guru akan mengetahui masalah anak dirumahnya. Apabila setiap anak diketahui problemnya secara totalitas, maka program pendidikan akan lebih mudah direncanakan untuk disesuaikan dengan minatnya. Kedua Panggilan orang tua; Selain mengadakan kunjungan ke rumah, pihak sekolah sesekali juga memanggil orang tua murid datang ke sekolah. Setelah datang, mereka diberi penjelasan tentang perkembangan pendidikan di lembaga tersebut. Mereka juga perlu diberi penjelasan khusus tentang perkembangan pendidikan anaknya. Ketiga Pertemuan; Dengan teknik ini berarti sekolah mengundang masyarakat dalam acara pertemuan khusus untuk membicarakan masalah atau hambatan yang dihadapi sekolah. Pertemuan ini sebaiknya diadakan pada waktu tertentu yang dapat dihadiri oleh semua pihak yang diundang. Sebelum pertemuan dimulai acaranya disusun terlebih dahulu. Oleh karena itu, setiap akan mengadakan pertemuan sebaiknya dibentuk panitia penyelenggara.

\section{c) Teknik Peragaan}

Hubungan sekolah dengan masyarakat dapat dilakukan dengan cara mengundang masyarakat melihat peragaan yang diselenggarakan sekolah. Peragaan yang diselenggarakan biasanya berupa pameran keberhasilan murid. Misalkan di TK menampilkan anak-anak bernyanyi, membaca puisi dan menari. Pada kesempatan itu kepala sekolah atau guru TK tersebut dapat menyampaikan program-program peningkatan mutu pendidikan dan juga masalah atau hambatan yang dihadapi dalam merealisasikan program-program itu.

\section{d) Teknik Elektronik}

Seiring dengan perkembangan teknologi elektronik maka dalam mengakrabkan sekolah dengan orang tua murid dan masyarakat pihak sekolah dapat menggunakan sarana elektronik, misalkan dengan telpon, televisi, ataupun radio, sekaligus sebagai sarana untuk promosi pendidikan.

\section{Proses Administrasi Husemas}

\section{1) Penyusunan Program}

Penyusunan program husemas memperhatikan dana yang tersedia, ciri masyarakat, daerah jangkauan, sarana atau media, 
dan teknik yang akan dilaksanakan dalam mengadakan hubungan dengan masyarakat. Jika perencanaan tidak memperhatikan hal-hal tersebut, di khawatirkan kegiatan tersebut tidak akan mencapai sasaran yang di inginkan.

\section{2) Pelaksanaan atau Pengorganisasian}

Pada dasarnya semua komponen sekolah dan pelaksanaan husemas. Oleh karena itu, tugas-tugas mereka perlu dipahami dan ditata, sehingga penyelenggara husemas dapat berjalan efektif dan efisien.

Dalam pelaksanaan husemas perlu diperhatikan koordinasi antara berbagai bagian dan kegiatan, dan di dalam penggunaan waktu perlu adanya sinkronisasi.

\section{3) Pengawasan}

Pengawasan pada administrasi hubungan sekolah dan masyarakat dapat berupa evaluasi. Husemas dapat di evaluasi melalui dua kriteria, yaitu:

a) Efektifitas, yaitu sejauh apa tujuan tercapai

b) Efisiensi, yaitu mengenai sumber dan potensi dengan baik.

\section{Peran personil sekolah dalam adminsitrasi Husemas}

Guru merupakan kunci penting dalam kegiatan husemas di sekolah menengah. Ada beberapa hal yang dapat dilakukan guru dalam kegiatan husemas itu, yaitu :
1) Membantu sekolah dalam melaksanakan teknik-teknik husemas.

2) Membuat dirinya lebih baik lagi dalam bermasyarakat.

3) Dalam melaksanakan semua itu guru harus melaksanakan kode etiknya (kode etik guru)

\section{KESIMPULAN}

Administrasi Husemas adalah hubungan dua arah antara sekolah dengan masyarakat untuk memusyawarahkan ide-ide dan informasi-informasi tertentu yang berguna bagi peningkatan mutu pendidikan. Tujuan hubungan sekolah dengan masyarakat yaitu: mengenalkan pentingnya sekolah bagi masyarakat, mendapatkan dukungan dan bantuan moril maupun financial yang diperlukan bagi pengembangan sekolah, memberikan informasi kepada masyarakat tentang isi dan pelaksanaan program sekolah, memperkaya atau memperluasprogram sekolah sesuai dengan perkembangan dan kebutuhan masyarakat, mengembangkan kerjasama yang lebih erat antara keluarga dan sekolah dalam mendidik anak.

\section{Daftar Pustaka}

Sagala, S. (2008). Manajemen Berbasis Sekolah dan Masyarakat, Jakarta: Nimas Multima h.

Aedi, dkk, (2013). Hubungan Sekolah dengan Masyarakat.Hal 278.

Mulyasa (2009). Hubungan Sekolah dengan Masyarakat. Hal 247-148'

Sagala,S. (2008). Manajemen Berbasis Sekolah dan Masyarakat Jakarta: Nimas Multima h. 


\title{
Administrasi Layanan Khusus
}

\author{
Asmaul Husnah \\ Universitas Negeri Padang \\ Indonesia \\ E-mail : asmaulhusnah072837@gmail.com
}

\begin{abstract}
Abstrak - The Special Services Administration is a service provided to students to facilitate, facilitate the teaching and learning process that aims to be more effective and more efficient in learning. Special services can be school transportation, as well as a place to study, or libraries, learning resources, school cafeteria, places of worship, laboratories and dormitories. Where this particular service can support student success.
\end{abstract}

Keywords-(Special Services Administration)

\section{I.PENDAHULUAN}

Administrasi Adalah membantu, melayani dan juga mengelola. Administrasi bertujuan untuk mempermudah serta membuat lebih efektif dan efisien dalam bekerja. Sedangkan Layanan khusus adalah layanan yang diberikan secara khusus kepada siswa untuk dapat mempermudah dan memperlancar dalam proses belajar mengajar(PBM). Layanan Khususnya dapat berupa transportasi sekolah, dan juga tempat belajar, atau perpustakaan, sumber belajar, cafeteria sekolah, tempat ibadah, laboratorium dan asrama. dimana layanan khusus ini dapat mendukung keberhasilan siswa. Hal ini sesuai dengan yang dikatakan seorang ahli yaitu adanya layanan khusus di sekolah ditujukan untuk memenuhi kebutuhan peserta didik dalam mendukung keberhasilan proses pembelajaran (Agustine, 2003).

Layanan khusus untuk siswa disekolah sangat dibutuhkan untuk dapat menunjang proses belajar mengajar agar dapat terlaksana sebagaimana mestiya, dengan terpenuhi semua kebutuhan siswa. Siswa dapat fokus pada belajar misalnya saja saat siswa butuh buku dan semua buku yang iya butuhkan ada di perpustakaan tentu lebih efektif dari pada harus beli buku dulu. Jika semua kebutuhan untuk menunjang kebutuhan siswa terpenuhi juga siswa dapat memanfaatkan semua layanan khususitu tidak menutup kemungjinan siswa akan mendapat hasil yang memuaskan untuk siswa itu sendiri tentunya.

Jadi administrasi Layanan Khusus adalah layanan yang diberikan kepada siswa agar dapat mempermudah, memperlancar dalam proses belajar mengajar yang bertujuan untuk lebih efektif dan lebih efisien dalam belajar. Manajemen layanan khusus di sekolah pada dasarnya ditetapkan dan di organisasikan untuk mempermudah atau memperlancar pembelajaran, serta dapat memenuhi kebutuhan khusus siswa di sekolah. Pelayanan khusus diselenggarakan di sekolah dengan maksud untuk memperlancar pelaksanaan pengajaran dalam rangka pencapaian tujuan pendidikan di sekolah. Pendidikan disekolah antara lain juga berusaha agar peserta didik senanatiasa berada dalam keadaan baik.

\section{Metode PENELITIAN}

Penelitian yang berjudul Administrasi Layanan Khusus ini menggunakan metode literature dimana metode ini menggunakan teknik mengumpulkan informasi dari berbagai berbagai sumber sehingga nantinya dapat menjadi sumber belajar juga bagi yang membutuhkan. Metode ini sangat efektif dan efesien karena peneliti mencari materi dari bukubuku, majalah, serta berbagai artikel yang sangat banyak dapat dijumpai sehingga sangat membantu. Sehingga Semua yang di tulis nantinya akan dapat dipertanggung jawabkan. Karena materi ini didapat dari jurnal, artikel serta dari buku yang peneliti baca.

\section{KAJIAN TEORI DAN PEMBAHASAN}

\section{A. Pengertian Administrasi Layanan Khusus}

Menurut UU No. 19 Tahun 2005 tentang Standar Nasional Pendidikan Bab II Pasal 4 yang memuat tentang adanya tujuan pendidikan nasional. Untuk memenuhi tugas dan tanggungjawab tersebut maka sekolah memerlukan suatu manajemen layanan khusus yang dapat mengatur segala kebutuhan peserta didiknya sehingga tujuan pendidikan tersebut. Administrasi layanan khusus di suatu sekolah merupakan bagian penting dalam Manajemen Berbasis Sekolah (MBS) yang efektif dan juga efisien dapat tercapai. Administrasi Layanan Khusus adalah layanan yang diberikan kepada siswa agar dapat mempermudah, memperlancar dalam proses belajar mengajar yang bertujuan untuk lebih efektif dan lebih efisien dalam belajar.

Administrasi layanan khusus merupakan bagian terpenting didalam sekolah. Administrasi layanan khusus sendiri di sekolah pada dasarnya untuk mempermudah atau memperlancar proses belajar ,serta dapat memenuhi kebutuhan khusus siswa di sekolah. Layanan khusus untuk siswa disekolah sangat dibutuhkan untuk dapat menunjang proses belajar mengajar agar dapat terlaksana sebagaimana mestiya, dengan terpenuhi semua kebutuhan siswa. Jika semua kebutuhan untuk menunjang kebutuhan siswa terpenuhi juga siswa dapat memanfaatkan semua layanan khususitu tidak menutup kemungjinan siswa akan mendapat hasil yang memuaskan untuk siswa itu sendiri tentunya.

\section{B. Jenis-jenis administrasi Layanan Khusus}

\section{1) Perpustakaan}


Perpustakaan adalah Layanan yang diberikan sekolah untuk peserta didik agar dapat lebih mengoptimalkan dalam belajar dan perpustakaan sangat penting bagi peserta didik, dimana mereka dapat belajar dengan tenang karna perpustakaan menuntut untuk tidak ada suara sehingga tidak berisik dan juga banyak buku-buku yang dapat di baca ada buku fiksi ataupun non fiksi serta untuk memenuhi tugas yang diberikan guru. Dengan adanya perpustakaan dapat menunjang prestasi siswa dimana banyaknya ilmu yang di dapat di perpustakaan dengan cara membaca.

Menurut (Supriyadi,1983) dalam buku Manajemen Peserta Didik oleh Ali Imron mendefinisikan perpustakaan sekolah sebagai perpustakaan yang diselenggarakan di sekolah guna menunjang program belajar mengajar di lembaga pendidikan formal seperti sekolah, baik sekolah tingkat dasar maupun menengah, baik sekolah umum maupun kejuruan.

(Yolanda \& Afriansyah, 2015).

\section{2) Labolatorium}

Laboratorium adalah layanan untuk dapat mendukung belajar dimana laboratorium ini tempat guru dan siswa melakukan kegiatan kerja ilmiah seperti pratikum, observasi, penelitian, demokrasi dan pembuatan model- model dalam rangka kegiatan belajar mengajar. Labor juga sangat menunjang prestasi siswa dimana siswa dapat mengembangkan ilmu yang iya terima di kelas dapat mengembangkannya di labor.

\section{3) UKS (Usaha Kesehatan Sekolah)}

Usaha Kesehatan Sekolah adalah layanan yang disediakan sekolah untuk melayani siswa jika peserta didik merasa kurang sehat saat belajar, peserta didik dapat beristirahat juga dapat meminta obat pada perawat, Dengan UKS dapat juga menunjang pprestasi siswa juga dimana jika siswa belajar tetapi sakit jadi tidak dapat focus saat belajar maka harus diobati terlebih dahulu baru bisa belajar.

\section{4) Kafetaria Sekolah}

Kafetaria atau warung ini bertujuan untuk dapat meningkatkan konsentrasi peserta didik, dimana jika peserta didik merasa tidak konsentrasi karena lapar dan peserta didik dapat makan terlebih dahulu. Karna ini juga mempengaruhi prestasi siswa dengan makan dulu, siswa yang kelaparan tentu tidak focus saat belajar.

\section{5) Sarana Ibadah}

Layanan khusus sarana ibadah merupakan layanan yang diberikan sekolah untuk beribadah serta untuk meningkatkan kerohanian bagi pesrta didik. Agar menjadi manusia yang baik dan beriman. Juga untuk membuat mereka menjadi berkarakter tinggi. Dengan ada nya sarana peribadatan di sekolahdapat juga dimanfaatkan untuk saran tempat pembelajaran di luar kegiatan proses belajar mengajar atau saat proses belajar berlangsung. Sarananya berupa mesjid atau musalla.

\section{6) Asrama}

Administrasi layanan khusus asrama biasanya diberikan kepada sekolah jenjang menengah atau pendidikan tinggi yang dimanfaatkan untuk peserta didik yang jauh dari orang tua, siswa juga dapat lebih optimal dalam belajar karena masih dalam lingkungan sekolah. Siswa juga lebih banyak menghabiskan waktu dengan teman- teman untuk belajar tentunya. selain itu asrama juga memiliki manfaat lain, yaitu : a. Tugas sekolah dapat diselesaikan secara bersama sama jika memiliki kesulitan dalam menyelesaikannya

b. Sikap dan tingkah laku peserta didik dapat di awasi oleh petugas asrama

c. Melatih kemandirian dan kedisplianan peserta didik.

\section{7) Tranportasi}

Sarana transportasi bagi peserta didik merupakan sarana penunjang untuk peserta didik dimana dapat memiliki banyak manfaat, salah satunya antar jemput ke sekolah. Sarana transportasi bagi peserta didik merupakan sarana penunjang untuk kelancaran proses belajar mengajar. Biasanya transportasi tidak hanya untuk mengantar jeput saja akan tetapi juga untuk urusan sekolah seperti ada olimpiade, cerdas cermat, dan tanding lainya. Dampaknya sendiri dari adanya layanan transportasi sekolah, dapat di rasakan oleh siswa,orang tua siswa, dan juga sekolah. Adanya transportasi sekolah dapat membantu siswa untuk lebih disiplin karena bisa datang pulang tepat waktu dan membuat orang tua lebih percaya akakn keselamatan anak mereka dari berangkat sekolah sampai ke pulang ke rumah kembali. Dengan kata lain,orang tua siswa tidak perlu khawatir mengenai keselamatan untuk keamanan ,efisensi nya terstandard

\section{8) Koperasi}

Layanan koperasi mendidik para peserta didik untuk dapat berwirausaha. Hal ini sangat membantu peserta didik di kehidupan yang akan datang. Koperasi adalah "suatu perkumpulan yang beranggotakan orang-orang atau badanbadan, yang memberikan masuk dan keluar sebagai anggota; dengan bekerja sama secara kekeluargaan menjalankan usaha, untuk mempertinggi kesejahteraan jasmaniah para anggotanya.

\section{Peranan Guru dalam Administrasi Layanan khusus}

1) Keterlibatan guru dalam administrasi perpustakaan misalnya memperkenalkan buku-buku kepada siswa.

2) Mengetahui jenis dan menguasai kriteria umum yang menentukan baik buruknya suatu koleksi buku-buku perpustakaan

3) Mempromosikan perpustakaan baik pemakaian maupun untuk pembinaannya. 


\section{KESIMPULAN}

Administrasi layanan khusus adalah memberi layanan secara khusus atau suatu usaha yang tidak secara langsung berkenaan dengan proses belajar mengajar di kelas. Tetapi secara khusus diberikan oleh sekolah kepada para siswamnya agar mereka lebih optimal dalam melaksanakan proses belajar. Pelayanan khusus di selenggarakan di sekolah dengan maksud untuk memperlancar pelaksanaan pengajaran dalam rangka pencapaian tujuan pendidikan di sekolah. Administrasi layanan khusus adalah suatu proses kegiatan memberikan pelayanan kebutuhan kepada peserta didik untuk menunjang kegiatan pembelajaran agar tujuan pendidikan bisa tercapai secara efektif dan efisien.

\section{Daftar Pustaka}

Agustine, D. (2003). Keefektifan Manajemen Layanan Khusus Sekolah dan Pengaruhnya terhadap motivasi dan prestasi Belajar Peserta Didik di SMA.

Afriansyah, H. (2019). Administrasi Layanan khusus. Padang: osf.io/sc6ap. Diambil dari https://osf.io/eqtfb/

Yolanda, R., \& Afriansyah, H. (2015). Administrasi Layanan Khusus Peserta Didik (pp. 3-10). pp. 3-10. padang. 


\title{
Administrasi ke-Tata Usahaan Sekolah
}

\author{
Asmaul Husnah \\ Universitas Negeri Padang \\ Indonesia \\ E-mail : asmaulhusnah07287@gmail.com
}

\begin{abstract}
Abstrak- The school administration Administrator is an educational administrative activity that manages the recording, collecting, storing data, and documents that can be used to assist leaders in decision making, correspondence affairs and Report on the school's activities.
\end{abstract}

\section{Keywords-(school administration Administrator)}

\section{I.PENDAHULUAN}

Administrasi menjadi hal yang terpenting bagi suatu organisasi, karena dengan administrasi yang baik akan menghasilkan organisasi baik pula tentunya. Administrasi sangat membantu dalam bentuk mengarsipkan, pengelolaan surat. Bahkan bukan itu saja tata ruang dan kantor juga sangat mempengeruhi. Untuk itulah peneliti akan membahas tentang Administrasi ke-tata usahaan sekolah.

Administrasi ke-Tata Usahaan sekolah adalah semua yang berhubungan dengan membantu mengirim, menerima, mengadakan, pencatatan, pengolahan yang digunakan langsung oleh sekolah dan bagi yang membutuhkan informasi tersebut juga demi kepentingan sekolah. Ketatausahaan menjadi penting karena ketatausahaan dapat membantu dan mempermudah subsistem yang lain seperti bagian kesiswaan, kurikulum, administrasi personel, dan lainnya. Dalam hal ini ada istilah yang disebut dengan mekanisme bantu artinya kegiatan ketatausahaan sekolah dapat dipergunakan untuk membantu pimpinan (Kepala Sekolah) dalam mengambil keputusan, sehingga dapat memperlancar dan meningkatkan efektivitas dan efisiensi proses administrasi, dengan data yang diperlukan.

Bila administrasi ketatausahaan berjalan dengan baik maka kegiatan yang menyangkut pembelajaran dan tujuan pembelajaran dapat berjalan dengan baik pula. Untuk itu, diperlukan staf tata usaha yang profesional dan kompeten dibidangnya.

\section{Metode PENELITIAN}

Penelitian ini berjudul Administrasi ke-Tata Usahaan sekolah yang membahas tentang mengirim, menerima, mengadakan, pencatatan, pengolahan yang digunakan langsung oleh sekolah dan bagi yang membutuhkan informasi tersebut juga demi kepentingan sekolah. Materi yang ditulis disini menggunakan metode literature, metode literature adalah mengumpulkan informasi dari berbagai informasi baik dari jurnal, artikel, buku dan masih banyak lagi. Menggunakan metode ini karena banyakya ilmu yang dapat peneliti petik dari berbagai sumber materi dan peneliti bisa lebih focus pada pembuatan artikel ini, karena tidak harus meneliti langsung, dikarenakan bahannya sudah ada di berbagai sumber materi terutama dari jurnal, karena banyak yang terbaru.

\section{KAJIAN TEORI DAN PEMBAHASAN}

\section{A. Pengertian Administrasi ke-Tata Usahaan Sekolah}

Tata usaha adalah adalah kegiatan yang dilakukan meliputi, membantu proses belajar mengajar, urusan kesiswaan, kepegawaian, peralatan sekolah, urusan infrasturcture sekolah, keuangan, bekerja di laboratorium, perpustakaan dan hubungan masyarakat. Ada juga yang menyebutkan bahwa Tata usaha adalah suatu bagian dari sekolah yang berfungsi sebagai pendukung kegiatan belajar mengajar agar berjalan lancar sesuai apa yang telah direncanakan dan bisa tercapai seperti apa yang diinginkan.

Administasi ke-Tata Usahaan Sekolah adalah kegiatan administrasi pendidikan yang mengelola pencatatan, pengumpulan, penyimpanan data, dan dokumen yang dapat dipergunakan untuk membantu pimpinan dalam pengambilan keputusan, urusan surat menyurat serta laporan mengenai kegiatan sekolah tersebut. Dalam kamus bahasa Indonesia : Tata Usaha ialah penyelenggaraan tulis menulis (keuangan dan sebagainya) diperusahaan, Negara dan sebagainya, sedangkan pinata usaha adalah orang yang menyelenggarakan tata usaha. Jadi administrasi ke-Tata Usahaan Sekolah itu terdiri dari beberapa kata:

\section{1) Pengumpulan}

Setiap informasi yang diterima di kumpulkan dalam berbagai cara dan juga dari berbagai informan.

2) Pencatatan

Pada saat pencatatan ini semua informasi yang diterima dicatat dan juga dilampirkan foto dan video kalau bisa sekalian rekaman suara sebagai dokumenasinya.

\section{3) Menggandakan}

Keterangan/informasi yang telah dihimpun dicatat dan diolah kemudian digandakan (diperbanyak sesuai kebutuhan) dengan berbagai cara.

4) Mengirim

Kegiatan ini dilakukan untuk menyampaikan informasi yang telah digandakan kepada pihak yang memerlukan dengan menggunakan berbagai saluran informasi, seperti edaran, surat elektronik, dan lain sebagainya

5) penyimpanan data 
Informai yang sudah didapat tadi disimpan agar dapat menyajikan kembali informasi sehingga lebih berguna.

\section{B. Proses Administrasi ke-Tata Usahaan Sekolah}

\section{1) Persuratan}

Tata cara persuratan di lingkungan departeman pendidikan dan kebudayaan di atur dalam keputusan menteri pendidikan dan kebudayaan (kepmen dikbud) republik Indonesia nomor 091/U1995 tanggal 25 April 1995 tentang pedoman tata persuratan dan kearsipan dan kearsipan di lingkungan depertemen pendidikan dan kebudayaan. Menurut kepmen dikbud nomor 091/U1995 surat adalah suatu sarana komunikasi yang digunakan untuk menyampaiakan informasi tertulis oleh satu pihak kepada pihak lain. Berikut jenis- jenis surat:

\section{a) Surat dinas}

Surat yang berisi hal penting berkenaan dengan administrasi pemerintah dan pembangunan yang dibuat oleh lembaga pemerintah.

\section{b) Nota Dinas}

Surat yang dibuat oleh atasan kepada bawahan atau oleh bawahan kepada atasan atau setingkat yang berisi catatan singkat tentang suatu pokok persoalan kedinasan.

\section{c) Memo}

Catatan singkat yang diketik atau ditulis tangan oleh atasan kepada bawahan tentang pokok persoalan kedinasan.

\section{d) Surat Pengantar}

Surat yang ditujukan kepada seseorang atau pejabat yang berisi penjelasan singkat tentang surat, dokumen dan atau barang, bahan lain yang dikirimkan.

\section{e) Surat Kawat atau Telegram}

Surat singkat dengan menggunakan kata-kata biasa dan atau kata sandi mengenai hal yang perlu cepat disampaikan melalui telegram.

\section{f) Surat Keputusan}

Surat yang berisi keputusan tentang suatu hal yang ditetapkan pleh pejabat yang berwewenang untuk itu.

\section{g) Surat Edaran}

Surat yang berisi penjelasan/petunjuk cara melaksanakan peraturan perundang-undangan dan atau perintah yang telah ada.

\section{h) Surat Undangan}

Surat pemberitahuan kepada seseorang untuk menghadiri acara pada waktu dan tempat yang telah ditentukan.

\section{i) Surat Tugas}

Surat yang berisi penugasan dari pejabat yang berwenang kepada seseorang untuk melaksanakan kegiatan.

\section{j) Surat Kuasa}

Surat yang berisi kewenangan penerima kuasa untuk bertindak atau melakukan kegiatan atas nama pemberi kuasa.

\section{k) Surat Pengumuman}

Surat yang berisi pemberitahuan mengenai sesuatu hal disertai pertanggungjawaban atau pernyataan tersebut.

\section{l) Surat Pernyataan}

Surat yang menyatakan kebenaran suatu hal disertai pertanggungjawaban atau pernyataan tersebut.

\section{m) Surat Keterangan}

Surat surat yang berisi keterangan suatu hal agar tidak menimbulkan keraguan.

\section{n) Berita Acara}

Surat yang berisis laporan tentang suatu kejadian atau peristiwa mengenai waktu. tempat, keterangan, dan petunjuk lain sehubungan dengan kejadian/peristiwa tersebut.

\section{2) Kearsipan}

\section{a) Azas penataan arsip}

Azasnya yaitu azas sentralisasi, desentralisasi dan gabungan. Sentralisasi adalah azas penataan arsip yang dipusatkan pada satu unit. Desentralisasi adalah azas penataan arsip pada unit-unit dalam organisasi. Dan gabungan adalah gabungan antara azas sentralissasi dan azas desentralisasi.

\section{b) Sistem penataan arsip}

Sistem penataan arsip harus sesuai dengan, berdasarkan masalah, abjad, tanggal, nomor, wilayah.

\section{c) Prosedur penataan arsip}

Dalam prosedur dari penataan sendiri dimulai dari meneliti arsip yang akan disimpan, mengelompokkan arsip, meneliti kesesuaian lampiran, mengklasifikasikan arsip, mengindeks arsip dengan cara memberi ciri khas atau tanda suatu arsip, menyusun arsip sesuai dengan sistem penyimpanan menurut pola.

\section{Tata Ruang Kantor/Sekolah}

\section{1) Pengertian tata ruang kantor}

Tata ruang kantor adalah pengaturan perabotan, mesin, dan sebaginya didalam ruangan yang tersedia.

\section{2) Tujuan}

Tujuan dari tata letak kantor/ sekolah adalahuntuk mencegah penghamburan tenaga dan waktu pelaksanaan kerja, 
menjamin kelancaran proses pekerjaan, memungkinkan pemakaian ruangan secara efisien, mencegah para pegawai lain menganggu atau terganggu, menciptakan kenyamanan bekerja bagi para pegawai, memberikan kesan yang baik bagi para pegawai, danjuga tentunya untuk memberi kesan baik untuk tamu.

3) Jenis-jenis tata ruang kantor/sekolah

Ada beberapa jenis tata letak berikut beserta penjelasannya:

a) Tata Ruang Tertutup

Suatu tata ruang dikatakan terpisah-pisah atau tertutup apabila susunan ruang untuk bekerja terbagi-bagi dalam beberapa bagian.

\section{b) Tata Ruang Terbuka}

Dalam susunan ini ruang yang dipergunakan untuk ruang bekerja tidak dipisah pisahkan atau tidak menggunakan penyekat, tetapi semua aktivitasnya dilaksanakan.

\section{Peran guru dalam administrasi ketatausahaan sekolah}

1) Merencanakan penggunaan ruang-ruang di sekolah

2) Merumuskan kebijakan tentang pembagian tugas mengajar guru-guru

3) Menyelidiki buku-buku sumber bagi guru dan bukubuku pelajaran bagi murid-murid

4) Berperan dalam hal surat-menyurat di lingkungan sekolah
5) Berperan sebagai Penerima, Penyortir, Pencatat, Pengarah, Pengolah, Peñata arsip pada proses surat menyurat.

\section{KESIMPULAN}

Administrasi ke-Tata Usahaan sekolah adalah semua yang berhubungan dengan membantu mengirim, menerima, mengadakan, pencatatan, pengolahan yang digunakan langsung oleh sekolah dan bagi yang membutuhkan informasi tersebut juga demi kepentingan sekolah. Proses dari administrasi ke-Tata Usahaan sekolah ada dua yaitu persuratan dan juga kearsipan.

\section{Daftar Pustaka}

Panzola, N. F. (2019). Administrasi Tata usaha. Diambil dari https://osf.io/preprints/inarxiv/a4jt9/

Kosasih, A., Sos, S., \& Pertama, P. (2009). Tata Ruang, Perabot dan Perlengkapan Perpustakaan Sekolah. Retrieved January, 5, 2018. Diambil dari http://www.academia.edu/download/32504764/Tata_Rua ng_Perabot_Dan_Perlengkapan.pdf. 


\title{
Supervisi Pendidikan
}

\author{
Asmaul Husnah \\ Universitas Negeri Padang \\ Indonesia \\ E-mail : asmaulhusnah07287@gmail.com
}

\begin{abstract}
Abstrak - Supervise education is the coaching to be able to solve a variety of problems together with the aim that education will be better later.
\end{abstract}

Keywords-(Supervise education)

\section{PENDAHULUan}

Keberhasilan dari pendidikan suatu sekolah tidak hanya sarana prasarana, keuangan, layanan khusus, humas, Ke-tata usahaan akan tetapi juga memerlukan supervise.Supervisi Pendidikan bertujuan untuk adanya pengawasan dalam setiap program pendidikan dengan adanya pengawasan tentunya ada penanggulangan dalam menyelesaikan masalah, masalah yang terjadi akan di usahakan untuk menyelesaikan dengan baik. Pengawasan juga bertujuan untuk mengawasi jalannya pendidikan.

Supervisi dipelukan untuk menyelesaikan masalah yang ada, dengan supervisi diharapkan dapat ditemukan solusi dari setiap permasalahan yang terjadi, dan memperbaiki pengajaran yang tidak berhasil / yang sedang mengalami masalah. Misalnya, memperbaiki metode yang digunakan guru saat proses belajar mengajar. Sehingga tujuan pembelajaran dapat tercapai dengan sebagaimana mestinya. Supervisi pendidikan itu sendiri adalah pembinaan kearah perbaikan situasi pendidikan. Pembinaan maksudnya yaitu melalui bimbingan sehingga mengalami peningkatan mutu mengajar belajar pada umumnya. Pembinaan kepada guru dan juga bekerja sama dengan instansi pemerintah serta sekolah lain sehingga bisa tukar pikiran dan dapat menggunakan metode yang tepat nantinya jika menemukan masalah yang serupa nantinya akan dipraktekkan langsung dengan peserta didik. Pengawasan juga berfungsi untuk mengendalikan agar tidak ada kesalahan nantinya saat poses mengajar.

\section{Metode Penelitian}

Metode yang digunakan untuk pembuatan artikel ini yaitu metode literature. Peneliti mencari berbagai informasi dengan berbagai bacaan baik dari artikel lain, jurnal-jurnal, bukubuku, majalah, dan masih banyak lagi sumber bacaan yang sesuai dan relevan dengan materi. Jurnal adalah salah satu bacaan peneliti alasan kenapa mengambil jurnal tentunya karena jurnal banyak yang terbaru dan juga jurnal itu banyak sehingga sangat membantu nantinya. Teknik ini dilakukan dengan tujuan sumber yang peneliti cari berkaitan dengan permasalahan yang sedang diteliti oleh peneliti sehingga mampu memecahkan permasalahan ataupun sumber tersbut mampu memperkuat penelitian yang dilakukan.

\section{KAJIAN TEORI DAN PEMBAHASAN}

\section{A. Konsep dasar supervisi pendidikan}

\section{1) Pengertian supervisi pendidikan}

Burton dan Bruckner (1951:1). Menyatakan : Supervisi adalah suatu teknik pelayanan yang tujuan utamanya mempelajari dan memperbaiki secara bersama-sama faktorfaktor yang mempengaruhi perumbuhan dan perkembangan anak. Drs. M. Ngalim Purwanto, dalam Administrasi Pendidikan "Supervisi adalah suatu aktivitas pembinaan yang direncanakan untuk membantu para guru dan pegawai lainnya dalam melakukan pekerjaan mereka secara efektif. Jadi dapat disimpulkan bahwa supervise pendidikan adalah pembinaan untuk dapat menyelesaikan berbagai masalah bersama-sama dengan tujuan agar pendidikan akan lebih baik lagi nantinya.

\section{2) Tujuan supervisi pendidikan}

a) Membina kepala sekolah dan guru-guru untuk lebih mengetahui pendidikan yang lebih baik.

b) Memperbesar kesanggupan kepala sekolah dan guruguru untuk mempersiapkan peserta didiknya untuk terjun langsung ke masyarakat nantinya.

c) Membantu kepala sekolah dan guru mengadakan diagnosis secara kritis terhadap aktivitas-aktivitasnya dan kesulitan-kesulitan mengajar belajar, serta menolong mereka merencanakan perbaikan-perbaikan ssehingga dapat meningkatkan pendidikan disekolah.

d) Meningkatkan kesadaran kepala sekolah dan guruguru serta warga sekolah lainnya terhadap tata kerja yang demokratis dan kooperatif, serta memperbesar kesediaan untuk tolong menolong.

e) Membantu pimpinan sekolah untuk mempopulerkan sekolah kepada masyarakat dalam pengembangan programprogram pendidikan.

f) Membantu kepala sekolah dan guru-guru untuk dapat mengevaluasi aktivitasnya dalam konteks tujuan-tujuan aktivitas perkembangan peserta didik.

g) Mengembangkan "esprit de corps" guru-guru, yaitu adanya rasa kesatuan dan persatuan (kolegialitas) antar guruguru.

3) Fungsi supervisi pendidikan

a) Mengkoordinasi semua usaha sekolah.

b) Memperlengkapi kepemimpinan sekolah. 
c) Memperluas pengalaman-pengalaman guru.

d) Menstimulasi usaha-usaha yang kreatif.

e) Member fasilitas dan penilaian yang terus-menerus.

f) Menganalisis situasi belajar-mengajar.

g) Memberikan pengetahuan dan keterampilan kepada setiap anggota staf.

h) Memberi wawasan yang lebih luas dan terintegrasidalam merumuskan tujuan-tujuan pendidikan dan meningkatkan kemampuan mengajar guru-guru.

\section{B. Ruang Lingkup Supervisi Pendidikan} berikut:

Ruang lingkup supervisi pendidikan meliputi beberapa hal

1) Supervisi manajerial bidang kurikulum

2) Supervisi manajerial bidang kesiswaan

3) Supervisi manajerial bidang pendidik dan tenaga kependidikan

4) Supervisi manajerial bidang sarana dan prasarana

5) Supervisi manajerial bidang keuangan

6) Supervisi manajerial bidang humas, dan

7) Supervisi manajerial bidang ketatausahaan

8) Supervisi akademik seputar pembelajaran, terkait metode, strategi sumber, dan evaluasi

9) Prinsip dasar/fundamental (fundamental/basic principle). Setiap pemikiran, sikap dan tindakan seorang supervisor harus berdasarkan suatu yang kokoh, seperti pancasila sebagai dasar falsafah negara kita.

10)Prinsip Praktis. Selain prinsip fundamental, dalam pelaksanaan sehari-hari, seorang supervisor berpijak pada prinsip praktis yang meliputi prinsip positif dan negatif.

11)Prinsip positif, yaitu pedoman yang harus dijalankan oleh supervisor agar pembinaan yang dilakukan berjalan sukses.

\section{C. .Prinsip supervisi pendidikan}

1) Prinsip Ilmiah (Scientific)

Prinsip ilmiah mengandung ciri-ciri sebagai berikut:

a) Kegiatan supervisi dilaksanakan berdasarkan data objektif yang diperoleh dalam kenyataan pelaksanaan proses belajar mengajar.

b) Untuk memperoleh data perlu diterapkan alat perekam data, seperti angket, observasi, percakapan pribadi, dan seterusnya.

c) Setiap kegiatan supervisi dilaksanakan secara sistematis, berencana dan kontinu.

\section{2) Prinsip Demokratis}

Servis dan bantuan yang diberikan kepada guru berdasarkan hubungan kemanusiaan yang akrab dan kehangatan sehingga guru-guru merasa aman untuk mengembangkan tugasnya. Demokratis mengandung makna menjunjung tinggi harga diri dan martabat guru, bukan berdasarkan atasan dan bawahan, tapi berdasarkan rasa kesejawatan.

\section{3) Prinsip kerjasama}

Mengembangkan usaha bersama atau menurut istilah supervisi 'sharing of idea, sharing of experience', memberi support mendorong, menstimulasi guru, sehingga mereka merasa tumbuh bersama.

\section{4) Prinsip konstruktif dan kreatif}

Setiap guru akan merasa termotivasi dalam mengembangkan potensi kreativitas kalau supervisi mampu menciptakan suasana kerja yang menyenangkan, bukan melalui cara-cara menakutkan.Karena kalau menekutkan mereka tidak bekerja dengan senang melainkan karena ketakutan.

\section{Peranan supervisi pendidikan}

\section{1) Koordinator}

Sebagai koordinator harus bisa mengkoordinasi program belajar-mengajar, tugas-tugas anggota staf berbagai kegiatan yang berbeda-beda diantara guru, semua yang terjadi harus terkoordinasi sehingga dapat menanggulangi permasalahan yang terjadi dan berusaha agar selalu berjalan sebagaimana mestinya.

\section{2) Konsultan}

Sebagai seorang konsultan harus bisa memberi bantuan, bersama mengkonsultasikan permasalahan yang sedang dialami guru baik secara individual maupun secara kelompok.

\section{3) Pemimpin kelompok}

Sebagai pemimpin kelompok harus bisa memimpin semua staf guru dalam mengembangkan potensi kelompok, pada saat mengembangkan kurikulum, materi pelajaran dan kebutuhan professional guru secara bersama-sama.

\section{4) Evaluator}

Sebagai evaluator ia dapat membantu guru dalam menilai hasil dan proses belajar, dapat menilai kurikulum yang sedang dikembangkan saat ini. 


\section{Daftar Pustaka}

\section{KESIMPULAN}

Supervisi Pendidikan yaitu suatu upaya didalam pendidikan untuk mengadakan evaluasi terhadap proses pembelajaran guna meningkatkan efisiensi dan efektivitas guru dalam pembelajaran. Dari supervisi pendidikan , nantinya akan terlihat permasalahan yang sedang terjadi didalam pembelajaran dan mampu menemukan solusi yang tepat untuk menyelesaikan permasalahan.
Prasojo, L. D. (2011). Supervisi pendidikan. Yogyakarta: GayaMedia.Diambil dari

http://staff.uny.ac.id/sites/default/files/tmp/Makalah\%20 Supervisi\%20perhutani.pdf

Rizki, M., \& Afriansyah, H. (1982). Administrasi dan SupervisiPendidikan. Diambil dari

https://osf.io/3v6ae/download/?foa=pdf 


\title{
Proses dan Teknik Supervisi Pendidikan
}

\author{
Asmaul Husnah \\ Universitas Negeri Padang \\ Indonesia \\ E-mail : asmaulhusnah07287@gmail.com
}

\begin{abstract}
Abstrak- Supervision is a supervisory action that aims to supervise a thing in order to reach the destination accordingly. The supervision process is a series of Kagiatan performed when conducting supervision. The supervision process has three phases: planning, implementation, and evaluation.
\end{abstract}

Keywords-(Supervision, Education supervision, processes and techniques)

\section{PENDAHULUAN}

Pendidikan adalah salah satu unsur paling penting dalam kehidupan manusia yang merupakan proses pembentukan pribadi lebih baik dan juga berkarakter. Setiap jenjang pendidikan formal selalu diadakan supervise, dan dengan adanya supervise dapat memperbarui pendidikan. Setiap pelaksanaan program pendidikan memerlukan adanya pengawasan atau supervisi dan supervisor bertanggung jawab dalam munculnya suatu yang efektif dan efisien dalam program tersebut.

Supervisi ialah suatu aktivitas pembinaan yang direncanakan untuk membantu para guru dan pegawai sekolah dalam melakukan pekerjaan secara efektif (Purwanto, 2012). Proses supervisi ada tiga yaitu perencanaan, pelaksanaan, dan evaluasi dan nantinya tindak lanjut.

Teknik adalah alat yang digunakan oleh supervisior untuk melaksanakan pengawasan kepada guru-guru di sekolah, teknik yang digunakan juga banyak baik secara kelompok maupun secara perorangan atau dengan cara langsung bertatap muka dan cara tak langsung bertatap muka atau melalui media komunikasi.

\section{METODE PENELITIAN}

Artikel ilmiah hendaknya disusun dengan metode dan langkah-langkah yang sistematis untuk memudahkan melakukan penelitian. Pada artikel ini, peneliti menggukan metode studi literatur dengan cara mengumpulkan literatur (bahan-bahan materi) yang bersumber dari buku, jurnal, dan sumber lainnya terkait ilmu tentang Administrasi Pendidikan. Teknik ini dilakukan dengan tujuan sumber yang peneliti cari berkaitan dengan permasalahan yang sedang diteliti oleh peneliti sehingga mampu memecahkan permasalahan ataupun sumber tersbut mampu memperkuat penelitian yang dilakukan. Selain itu peneliti juga menggunakan materi yang diberikan dosen pengampu dan menyimpulkannya dalam artikel ini.

\section{KAJIAN TEORI DAN PEMBAHASAN}

\section{A. Proses Supervisi Pendidikan}

Supervisi menurut Rifai (1982) merupakan suatu proses, yaitu serangkaian kegiatan yang teratur dan beraturan serta berhubungan satu sama lain dan diarahkan pada satu tujaun. Secara garis besar kegiatan dalam proses supervisi dapat di bagi atas 3 yaitu, perencanaan, pelaksanaan, dan evaluasi berikut penjelasan tentang ketiganya:

\section{1) Perencanaan supervisi pendidikan}

Perencanaan supervisi perlu disusun oleh supervisor agar pelaksaan supervisi dapat terarah dan jelas. Jadi sebelum supervisior melakukan pengawasan perlu menyiapkan perencanaan perencanaannya menyangkut:

a) Tujuan supervisi

b) Alasan mengapa kegiatan tersebut perlu dilakuka

c) Bagaiman (metode atau teknik) mencapai tujuan yang telah dirumuskan

d) Siapa yang akan dilibatkan atau diikutsertakan dalam kegiatan-kegiatan yang akan dilakukan

e) Waktu pelaksanaannya

f) Hal yang diperlukan dalam pelaksanaannya serta secara memperoleh hal-hal tersebut.

\section{2) Pelaksanaan supervisi pendidikan}

a) Mengumpulkan data

Proses supervisi yang pertama yaitu dengan mengumpulkan data . Data ini nantinya berupa data kekurangan atau kelemahan dari guru data murid, guru, program pengajaran, alat atau fasilitas, dan situasi kondisi yang ada.

\section{b) Penilaian}

Data yang sudah dikumpulkan diolah, kemudian di nilai. Penilaian ini dilakukan terhadap keberhasilan murid, guru, serta faktor-faktor menunjang dan menghambat dalam proses belajar mengajar.

\section{c) Deteksi kelemahan}

Supervisor menari kelemahan atau kekurangan guru dalam mengajar. Dalam rangka mendeteksi kelemahan, supervisor memperhatikan beberapa hal yang berkaitan dengan pelaksanaan tugas guru. 


\section{d) Memperbaiki kelemahan}

Jika melalui deteksi temukan kelemahan dan kekurangan, maka pada tahap ini dilakukan perbaikan atau peningkatan kemampuan. Memperbaiki kelemahan dan kekurangan tersebutdapat dilakukan dengan cara memberikan informasi langsung atau tidak langsung demonstarsi mengajar, kunjungan kelas /kunjungan sekolah, memberikan tugas bacaan, memberikan kesempatan mengikuti penataran dalam berbagai bentuk dan sebagainya.

\section{e) Bimbingan dan pengembangan}

Dalam pelaksaan supervisi , supervisor perlu memberikan bimbingan kepada guru agar apa yang diperolehnya diterapkan atau di aplikasikan dalam proses belajar mengajar yang dilakukannya. Bimbingan dan pengembangan ini antara lain dilakukan dengan cara kunjungan kelas, pertemuan pribadi, observasi dan diskusi dalam rangka penggunaan teknik supervise.

\section{3) Evaluasi}

Pada akhir supervisi dilakukan evaluasi, evaluasi bertujuan untuk menilai hasil dari pelaksanannya . Proses supervisi berkaitan dengan usaha supervisor membantu meningkatkan kemampuan guru, karena itu yang menjadi sasaran dalam evaluasi proses adalah guru. hal-hal yang perlu dievaluasi adalah kelebihan dan kelemahan guru; kemampuan dalam kegiatan belajar mengajar dan kemajuan/peningkatan; perkembangan kreativitas, semangat kerja, serta situasi dan suasana sekolah.

Terakhir evaluasi pelaksanaan supervise, sasarannya adalah supervisor . dalam hal ini supervisor perlu menilai apa yang dilakukannya, mulai dari tujuan yang dirumuskan , metode dan teknik yang digunakan, sikap kepemimpinan dan kemampuan berkomunikasi.

\section{B. Teknik Supervisi Pendidikan}

Berikut teknik- teknik individual supervisi yaitu :

\section{a) Teknik kunjungan kelas}

Pada teknik kunjungan ini supervisior melakukan kunjungan didalam kelas baik gurunya ada ataupun gurunya sedang tidak ada.

\section{b) Teknik Obsevasi kelas}

Pada teknik observasi kelas ini supervisior mengamati langsung saat proses belajar mengajar di kelas yang bersangkutan.

\section{c) Percakapan Pribadi}

Pada teknik percakaban pribadi ini supervisior melakukan percakapan langsung dengan guru tentang keluhan- keluhan guru serta keluhan pada saat mengajar.

\section{d) Percakapan kelompok}

Pada teknik percakapan kelompok dilakukan berkelompok oleh supervisior bertujuan untuk dapat meningkatkan kepercayaan diri guru.

\section{e) Intervisitasi (mengunjungi sekolah lain)}

Pada teknik ini saling mengunjungi antara guru yang satu dengan guru yang lain yang sedang mengajar. Sehingga dapat mendapat pengalaman baru.

\section{f) Penyeleksi Berbagai Sumber Materi untuk Belajar}

Tenik supervisi ini berkaitan dengan aspek - aspek belajar mengajar. Dalam usaha memberikan pelayanan profesional kepada guru, supervisor pendidikan akan menaruh perhatian terhadap aspek - aspek proses belajar mengajar sehingga diperoleh hasil yang efektif.

\section{g) Menilai Diri Sendiri}

Guru dan supervisior menilai kekurangan masing-masing sehingga dapat meningkatkan hubungan.

\section{h) Supervisi yang Memakai Para Siswa}

Pada teknik guru supervisior menanyakan langsung kepada siswa tentang permasalahan di kelas, juga tentang cara guru mengajar.

\section{2) Teknik Kelompok Supervisi}

\section{a) Penemuan orientasi Bagi Guru Baru}

Pertemuan orientasi adalah pertemuan antara supervisor dengan guru terutama guru baru untuk mengenalkan lingkungan kerja baru.

b) Rapat Guru

Rapat Guru adalah teknik supervisi kelompok melalui rapat guru yang dilakukan untuk membicarakan proses pembelajaran, dan upaya atau cara meningkatkan profesi guru.

\section{c) Studi Kelompok Antar Guru}

Studi kelompok antara guru adalah suatu kegiatan yang dilakukan oleh sejumlah guru yang memiliki keahlian dibidang studi tertentu.

\section{d) Diskusi}

Diskusi adalah tukar pikiran atau pendapat, melalui suatu percakapan tentang masalah untuk mencari alternatif pemecahannya.

\section{e) Workshop}

Workshop adalah suatu kegiatan belajar kelompok yang terjadi dari sejumlah pendidik yang sedang memecahkan masalah melalui percakapan dan bekerja secara kelompok

\section{f) Tukar Menukar Pengalaman}

Tukar menukar pengalaman "Sharing of Experince" suatu teknik perjumpaan dimana guru menyampaikan pengalaman masing-masing dalam mengajar terhadap topik-topik yang sudah diajarkan, saling memberi dan menerima tanggapan dan saling belajar satu dengan yang lain.

\section{g) Teknik Diskusi Panel}


Merupakan suatu kegiatan kelompok dalam situasi tatap muka,bertukar informasi atau untuk memutuskan sesuatu keputusan tentang masalah tertentu.

\section{h) Teknik Seminar}

Seminar adalah suatu rangkaian kajian yang diikuti oleh suatu kelompok untuk mendiskusikan, membahas dan memperdebatkan suatu masalah yang berhubungan dengan topik.

\section{i) Teknik Simposium}

Kegiatan mendatangkan seorang ahli pendidikan untuk membahas masalah pendidikan. Simposium menyuguhkan pidato-pidato pendek yang meninjau suatu topik dari aspekaspek yang berbeda.

\section{j) Teknik Demonstrasi Mengajar}

Usaha peningkatan belajar mengajar dengan cara mendemonstrasikan cara mengajar dihadapan guru dalam mengenalkan berbagai aspek dalam mengajar di kelas oleh supervisor.

\section{k) Teknik Buletin Supervisi}

Suatu media yang bersifat cetak dimana disana didapati peristiwa-peristiwa pendidikan yang berkaitan dengan cara cara mengjar tingkah laku siswa,dan sebagainnya.Diharapkan ini dapat membantu guru untuk menjadi lebih baik.

\section{l) Organisasi Profesi}

Organisasi Guru Indonesia adalah PGRI yaitu lembaga profesi yang melindungi guru secara lembaga dalam segala sesuatu yang akan merusak citra guru baik dari dalam ataupun dari luar anggotanya dan sekaligus memperjuangkan hak dan kewajibanya secara hukum kepada semua pihak yang langsung atau tidak langsung dengan guru.

\section{KESIMPULAN}

Supervisi adalah suatu tindakan pengawasan yang tujuannya untuk mengawasi suatu hal agar dapatm mencapai tujuan dengan sebagaimana mestinya. Proses supervisi merupakan rangkaian kagiatan yang dilaksanakan ketika melakukan supervisi. Proses supervisi ada tiga tahapan yaitu perencanaan, pelaksanaan, dan evaluasi. Supervisi memiliki banyak teknik untuk melaksanakan supervise dan dengan banyaknya teknik ini diharapkan pada supervisior dapat melaksankan tugas dengan baik.

\section{Daftar Pustaka}

Purwanto, N. (2012). Administrasi dan Supervisi Pendidikan. Bandung: Remaja Rosdakarya. 


\title{
Kepemimpinan Pendidikan
}

\author{
Asmaul Husnah \\ Universitas Negeri Padang \\ Indonesia \\ E-mail : asmaulhusnah07287@gmail.com
}

\begin{abstract}
Abstrak - Leadership education is the ability and process of influencing, guiding, coordinating and mobilizing others that have to do with the development of educational science and education implementation so that the activities executed can be more effective In achieving the objectives of education and teaching. The primary role of leadership is influencing others to achieve a predetermined goal.. Good leaders will bring their subordinates to the better not the other way around.
\end{abstract}

Keywords-(Leadership education)

\section{PENDAHULUAN}

Pendidikan adalah jalannya menuju kesuksesan dan pendidikan mampu membuat derajat manusia jauh lebih tinggi lagi di sisi allah SWT. Pendidikan adalah proses pengembangan individu secara utuh yang mencakup aspek kognisi, afeksi, dan psikomotor sehingga terbentuk pribadi yang berpengetahuan, berkarakter, dan terampil. Menurut Atmosudirdjo (dalam Purwanto, 1990: 25), Kepemimpinan dapat dirumuskan sebagai suatu kepribadian seseorang yang mendatangkan keinginan pada kelompok orang-orang untuk mencontohnya atau mengikutinya, atau yang memancarkan suatu pengaruh yang tertentu, suatu kekuatan yang sedemikian rupa sehingga membuat sekelompok orang-orang mau melakukan apa yang dikehendakinya.

Kepemimpinan pendidikan adalah suatu kemampuan dan proses mempengaruhi, membimbing, mengkoordinir dan menggerakkan orang lain yang ada hubungannya dengan pengembangan ilmu pendidikan dan pelaksanaan pendidikan agar kegiatan yang dijalankan dapat lebih efektif didalam pencapaian tujuan - tujuan pendidikan dan pengajaran. Kepemimpinan merupakan bagian penting dari manajemen yaitu merencanakan dan mengorganisasi, tetapi peran utama kepemimpinan adalah mempengaruhi orang lain untuk mencapai tujuan yang telah ditetapkan.. Pemimpin yng baik akan membawa bawahannya menjadi lebih baik lagi bukan sebaliknya.Hal ini berarti mampu mempengaruhi terhadap orang atau kelompok untuk mencapai hasil yang diinginkan dan ditetapkan bersama.

\section{METODE PENELITIAN}

Artikel ilmiah biasanya dibuatdengan bahan bahan yang terpercaya danjuga sistematis atau juga bisa melakukan praktek langsung ke lapangan. Pada artikel ini peneliti menggunakan metode literature dimana metode literature ini terdiri dari berbagai macam sumber seperti jurnal, artikel, Buku, majalah, dan masih banyak lagi yang pasti juga sesuai dengan materi yang akan dibahas di artikel ini tentunya.
Teknik ini dilakukan dengan tujuan sumber yang peneliti cari berkaitan dengan permasalahan yang sedang diteliti oleh peneliti sehingga mampu memecahkan permasalahan ataupun sumber tersbut mampu memperkuat penelitian yang dilakukan. Selain itu peneliti juga menggunakan materi yang diberikan dosen pengampu dan menyimpulkannya dalam artikel ini.

\section{KAJIAN TEORI DAN PEMBAHASAN:}

\section{A. Pengertian Kepemimpinan Pendidikan}

Menurut Atmosudirdjo (dalam Purwanto, 1990: 25), Kepemimpinan dapat dirumuskan sebagai suatu kepribadian seseorang yang mendatangkan keinginan pada kelompok orang-orang untuk mencontohnya atau mengikutinya, atau yang memancarkan suatu pengaruh yang tertentu, suatu kekuatan yang sedemikian rupa sehingga membuat sekelompok orang-orang mau melakukan apa yang dikehendakinya.

Kepemimpinan Pendidikan adalah kemampuan dan proses mempengaruhi, membimbing, mengkoordinir dan menggerakkan orang lain yang ada hubungannya dengan pengembangan ilmu pendidikan dan pelaksanaan pendidikan agar kegiatan yang dijalankan dapat lebih efektif didalam pencapaian tujuan - tujuan pendidikan dan pengajaran. Seorang pemimpin harus memiliki kelebihan dari pada bawahan dan juga harus bisa mempengaruhi dalam hal positif sehingga dapat terjadi sesuai dengan rencana awal. Pemimpin yang buruk akan membawa pengaruh buruk juga tentunya.

Pemimpin mempunyai kekuasaan untuk mengatur anggotanya tetapi kekuasaan yang diberikan harus digunakan secara bertanggung jawab. Bertanggung jawab maksudnya adalah tidak menggunakan kekuasaan yang telah diberikan untuk kepentingan dirinya sendiri atau individu, tidak otoriter atau semua keputusan harus berdasarkan keputusannya tetapi bukan hasil musyawarah anggotanya.

\section{B. Fungsi Kepemimpinan Pendidikan}

\section{1) Fungsi Instruktif}

Fungsi pemimpinan dan kepemimpinan adalah sebagai komunikator yaitu melakukan perintah yang berupa isi, cara melakukan, waktu pelaksanaan dan tempat melakukan perintah agar keputusan terwujud dengan efektif. Artinya, pemimpin berfungsi untuk memberi perintah dan yang dipimpin berfungsi melaksanakan perintah pemimpin.

2) Fungsi Konsultatif 
Fungsi konsultatif yaitu dapat berkomunikasi dua arah. Tujuannya adalah sebagai upaya menetapkan sebuah keputusan yang membutuhkan pertimbangan dan konsultasi dari orang yang dipimpinnya.

\section{3) Fungsi Partisipasi}

Fungsi partipasi adalah pemimpin bisa melibatkan anggotanya dalam proses pengambilan keptusan ataupun dalam pelaksanaan keputusan.

\section{4) Fungsi Delegasi}

Pemimpin memiliki fungsi delegasi yaitu suatu bentuk kepercayaan seorang pemimpin kepada seseorang yang diberi mandat untuk melaksanakan dan bertanggung jawab atas pelimpahan wewenang.

\section{5) Fungsi Pengendalian}

Dalam melaksanakannya, pemimpin dan kepemimpinan juga bisa melakukan bimbingan, pengarahan, koordinasi, dan pengawasan, terhadap kegiatan para pengikut atau bawahannya.

\section{Gaya kepemimpinan Kepala sekolah}

Menurut Purwanto (2012) gaya kepemimpinan adalah suatu cara atau teknik seseorang dalam menjalankan suatu kepemimpinan. Gaya kepemimpinan dapat pula diartikan sebagai norma perilaku yang digunakan seseorang saat mencoba mempengaruhi perilaku orang lain seperti yang ia lihat. Dalam hal ini usaha menselaraskan persepsi diantara orang yang akan mempengaruhi perilaku dengan yang akan dipengaruhi menjadi amat penting kedudukannya.

Kepala sekolah memiliki gaya kepemimpinannya sendiri karena memiliki watak, dan sifat yang berbeda dengan kepala sekolah yang lain. Menurut Wahjosumidijo ada empat pola perilaku kepemimpinan yang lazim disebut gaya kepemimpinan yaitu perilaku instruktif, konsulatif, partisipatif, dan delegatif.

\section{1) Perilaku instruktif}

Komunikasi satu arah, pimpinan membatasi peranan bawahan, pemecahan masalah dan pengambilan keputusan menjadi tanggung jawab pemimpin pelaksanaan pekerjaan diawasi dengan ketat.

\section{2) Perilaku konsultatif}

Pemimpin yang masih memberikan instruksi yang cukup besar serta menentukan keputusan, diharapkan komunikasi dua arah dan memberikan supportif terhadap bawahan, pemimpin mau mendengar keluhan dan perasaan bawahan dalam mengambil keputusan, bantuan terhadap bawahan ditingkatkan tetapi pelaksanaa keputusan tetap pada pemimpin.

3) Perilaku partisipatif

Control atas pemecahan masalah dan pengambilan keptusan antar pimpinan dan bawahan yang seimbang, pemimpin dan bawahan juga sama-sama terlibat dalam pemecahan masalah dan pengambilan keputusan, komunikasi dua arah makin meningkat, pemimpin mendengarkan secara intensif keluhan bawahannya, keikutsertaan bersama dalam pemecahan dan pengambilan keputusan makin bertambah.

4) Perilaku delegatif

Pemimpin mendiskusikan masalah yang dihadapinya dengan bawahan dan selanjutnya mendelegasikan pengambilan keputusan seluruhnya kepada bawahan, bawahan diberi hak menentukan langkah-langkah bagaiman keputusan dilaksanakan, dan bawahan diberikan wewenang untuk menyelesaikan tugas-tugas sesuai dengan keputusan sendiri.

\section{KESIMPULAN}

Kepemimpinan pendidikan adalah suatu kemampuan dan proses mempengaruhi, membimbing, mengkoordinir dan menggerakkan orang lain yang ada hubungannya dengan pengembangan ilmu pendidikan dan pelaksanaan pendidikan agar kegiatan yang dijalankan dapat lebih efektif didalam pencapaian tujuan - tujuan pendidikan dan pengajaran.

\section{Daftar Pustaka}

Mulyasa, 2011, Menjadi Kepala Sekolah Profesional, Bandung:Remaja Rosda Karya

Purwanto, N. (1990). Administrasi dan Supervisi Pendidikan. Bandung:Remaja Rosdakarya.

Purwanto, N. (2012). Administrasi dan Supervisi Pendidikan. Bandung:Remaja Rosdakarya. 